\title{
Iron Intake and Hemoglobin Levels in Stunting in Adolescent
}

\author{
Addistyane Puristasari, ${ }^{1}$ Siti Nur Fatimah, ${ }^{2}$ Faisal $^{3}$ \\ ${ }^{1}$ Faculty of Medicine Universitas Padjadjaran, ${ }^{2}$ Department of Medical Nutrition Faculty of \\ Medicine Universitas Padjadjaran, ${ }^{3}$ Department of Child Health Faculty of Medicine Universitas \\ Padjadjaran/Dr. Hasan Sadikin General Hospital Bandung
}

\begin{abstract}
Background: Growth problem, such as stunting is still a major issue in the world. The prevalence of stunting in Indonesia increases throughout the years. Chronic undernutrition in adolescent with stunting, low socioeconomic, and education levels in a family can contribute to low iron intake. Low iron intake leads to low hemoglobin level. This study aimed to compare iron intake and hemoglobin level between stunting and non-stunting adolescent.
\end{abstract}

Methods: This study was conducted to 59 respondents aged 11-14 years old from a Junior High School in Jatinangor, West Java from September to October 2014. Those respondents were divided into two groups: stunting and non-stunting group. This study was an analytic comparative study using cross-sectional method. Data were collected through body height measurement, hemoglobin level examination, and interviews of iron-containing food intake. The collected data were analyzed using t-test and Mann-Whitney U test.

Results: Twenty eight of 59 subjects were stunting and 31 were normal. The mean of hemoglobin level was $12.95(0.95)$ in stunting adolescent and 13.66 (1.35) in non-stunting adolescent. The mean iron intake was 23.9 (24.39) $\mathrm{mg} /$ day in stunting adolescent and 23 (22.6) $\mathrm{mg} /$ day in non-stunting adolescent. There was a difference of hemoglobin between those groups, but not in iron intake.

Conclusions: Stunting adolescent has lower hemoglobin levels compared to non-stunting adolescent. There is no difference of iron intake levels between stunting and non-stunting adolescent. [AM].2016;3(2):17580]

Keywords: Hemoglobin, iron intake, stunting

\section{Introduction}

Growth problems in children and adolescents, such as stunting, is still a major problem in the world. ${ }^{1}$ Stunting is an indicator of long-term chronic malnutrition with the characteristics of height/age under -2SD. According to the Health Research Association in 2013, the national prevalence of stunting in 2013 was $37.2 \%$. In adolescents, the prevalence is in the range of $32.3-40.2 \% .^{2}$ Genetic factors, nutrients, and hormones are the major factors in the height growth. Environmental factors such as socioeconomic, malnutrition, and chronic diseases play important roles in this process. $^{3}$

Nutrition is an important factor in the growth, especially in a period of rapid catch-up growth that occurs during early adolescent. Increasing of nutritional needs is not only on macro-nutrients, but also occurs on micronutrients, such as iron., ${ }^{4,5}$ Iron is an essential trace mineral for linear growth and body tissue proliferation. ${ }^{4}$ Chronic malnutrition obtained in stunting adolescent can be accompanied with a condition where a good source of iron intake is low, so that the iron levels in the body become lower. ${ }^{6}$ Low irons in the body will interfere hemoglobin synthesis, so that the subtraction of hemoglobin and oxygenation to the cells for the anabolic process in early adolescent will be intruded and cause a growth delay or failure. ${ }^{4}$ This situation makes hemoglobin levels in stunting adolescents lower than the hemoglobin levels in non-stunting adolescent. This study aimed to compare the iron intake and hemoglobin levels in stunting and nonstunting adolescents.

\section{Methods}

This study was a comparative analytical study with cross-sectional method. The study

Correspondence: Addistyane Puristasari, Faculty of Medicine, Universitas Padjadjaran, Jalan Raya Bandung-Sumedang Km.21, Jatinangor, Sumedang, Indonesia, Phone: +62 85732835296 Email: addistyane@gmail.com 
was conducted in Jatinangor, West Java from September to October 2014. All examinations which were performed in this study was approved by the Health Research Ethics Committee of Faculty of Medicine Universitas Padjadjaran .

Minimum sample size in this study was 23 samples for each group, stunting and nonstunting adolescents. Samples were selected by cluster random sampling technique. Junior High School 2 located in Cisempur village, Jatinangor was selected from 11 Junior High Schools in Jatinangor for representing the population. The students of this school spread in 4 villages in Jatinangor. Samples were taken from classes VII and VIII. Subjects were students whose height had been measured, aged 10-14 years, physically fit, and agreed to take peripheral blood sampling and interviewing food frequency questionnaire. If the subjects were known by anamnesis as taking iron supplement enhancer, were menstruating and had been suffering from chronic diseases, they were excluded in this study. Six of 66 students were excluded because they were menstruating when the examination was being held and the other subject was resigned, so the total numbers of samples in this study were 59 subjects.

Participants from eight classes of 14 existing classes conducted initial height measurement using a stadiometer Seca which were measured 3 times and took the average to determine the subject's stunting and nonstunting status. Subjects were classified in the stunting category when their height or age was deficit -2 standar deviation WHO $\mathrm{z}$-score and the non-stunting category was in -2 standar deviation of z-score using the WHO Anthroplus application.

Hemoglobin examination used Hemocue tool. Hemocue works in spectrophotometer. Precision and accuracy of the tool will be proportional to the hemoglobin by using cyanmethemoglobin. Hemoglobin levels obtained were expressed in grams/deciliter.

Both groups of subject were interviewed to fill the food intake questionnaires, Semiquantitative Food Frequency Questionnaire (Semi - FFQ). Semi - FFQ can describe the eating habits of a specific nutrient and will determine the amount of the estimated total daily intake of individuals. In this study, it was conducted a market survey and interviewed daily intake with the 24 hours recall method after a high iron content was selected from Food Composition Table (Daftar Komposisi Bahan Makanan, DKBM) Indonesia to identify the food source availability and the general public consumption. The populations of a market survey were who had similar characteristics to the subjects in the study area. Unusual food consumed was removed from the list.

The average of daily intake obtained was expressed in units of milligrams/day. The total of daily intake was categorized into two categories, those were the sufficient intake category and the less intake category based on the National of Recommended Dietary Allowances 2013, which were in accordance with their respective age. The intake category was considered to be sufficient if the total intake for female aged $10-12$ was $20 \mathrm{mg} /$ day, female aged 13-14 was $26 \mathrm{mg} /$ day, male aged 10-12 was $13 \mathrm{mg} /$ day, and male age 13-14 was $19 \mathrm{mg} /$ day. The intake category was less if the amount was less than the total intake of nutritional adequacy rate according to age respectively.

The collected data were tested for the normality of the data distribution with ShapiroWilk test. The distributed data were commonly analyzed using t-test and occasionally were analyzed using Mann Whitney $U$ rank test. T-test results showed significant if $\mathrm{p}<0.05$.

\section{Results}

The height measurement results obtained from an average subject's height was 146.9 (7.45), with an average male height 150.5 (8.8) and female height 144.6 (5.4).

Most of the respondents were female with a median age of 13 (11-14), while male students were 13 (12-14). Nearly 50\% of subjects' parental education only completed primary school. Most of the subjects' parents (39\%) worked in private sectors, followed by entrepreneur and employee.

The mean of hemoglobin level was $13.32(1.21) \mathrm{g} / \mathrm{dl}$. Normality of data test was conducted on hemoglobin levels according to sex distribution and the result was these data that were normally distributed. As the result of this study, the average of hemoglobin level in male was $13.73(1.47) \mathrm{g} / \mathrm{dl}$ and in female was $13.06(0.94) \mathrm{g} / \mathrm{dl}$. A t-test was conducted to analyze if there was a difference average of hemoglobin level between male and female. The $p$-value $(0.060)$ showed that there was no significant difference between $\mathrm{Hb}$ levels in both male and female.

The hemaglobin level of stunting and non stunting was calculated and tested for the data distribution. The result was the average of hemoglobin level in stunting group which 
Table 1 Characteristics of Subjects and Their Parents

\begin{tabular}{|c|c|c|c|c|}
\hline \multirow{2}{*}{ Variable } & \multirow{2}{*}{$\mathbf{F}$} & \multicolumn{2}{|c|}{ Height per age } & \multirow{2}{*}{ p-value } \\
\hline & & Stunting & Non-stunting & \\
\hline \multicolumn{5}{|l|}{ Sex } \\
\hline Male & 23 & 9 & 14 & 0.306 \\
\hline Female & 36 & 19 & 17 & \\
\hline \multicolumn{5}{|l|}{ Age (Years old) } \\
\hline 11 & 1 & 1 & 0 & 1.000 \\
\hline 12 & 12 & 6 & 6 & \\
\hline 13 & 30 & 13 & 17 & \\
\hline 14 & 16 & 8 & 8 & \\
\hline \multicolumn{5}{|l|}{ Parent's Occupation } \\
\hline Employee & 16 & 8 & 8 & 0.786 \\
\hline Private sector & 23 & 8 & 15 & \\
\hline Entrepreneur (self-employee) & 16 & 10 & 6 & \\
\hline Farmer & 2 & 1 & 1 & \\
\hline Government officer & 1 & 1 & 0 & \\
\hline House wife & 1 & 0 & 1 & \\
\hline \multicolumn{5}{|l|}{ Parent's educational background } \\
\hline Not graduated from elementary school & 2 & 2 & 0 & 1.000 \\
\hline Graduated from elementary school & 29 & 12 & 17 & \\
\hline Graduated from Junior High School & 14 & 8 & 6 & \\
\hline Graduated from Senior High School & 11 & 4 & 7 & \\
\hline Graduated from University & 3 & 2 & 1 & \\
\hline \multicolumn{5}{|l|}{ Number of family member } \\
\hline $3-4$ & 25 & 12 & 13 & 0.943 \\
\hline $5-9$ & 34 & 16 & 18 & \\
\hline Total & 59 & 28 & 31 & \\
\hline
\end{tabular}

was $12.95(0.90) \mathrm{g} / \mathrm{dl}$ and non-stunting group which was 13.66 (1.35) g/dl. The t-test was applied to determine differences of hemoglobin $(\mathrm{Hb})$ levels in stunting and nonstunting group.

The data of the stunting group were not normally distributed, therefore, t-test could not be performed. The alternative of $t$-test was Mann-Whitney U test.

From Table 2, it could be concluded that there was a significant differences in hemoglobin levels between stunting adolescent and non-stunting adolescent. The result showed that the $\mathrm{Hb}$ levels in stunting adolescent were lower than hemoglobin levels in non-stunting adolescent.
The results of dietary intake interview showed that 24 from 59 respondents consumed fried tofu as the most common food in their daily intake. Chicken parts like thigh, wing, and chest were consumed by more than $15 \%$ of the participants, while the chicken liver that had the highest source of iron was consumed by less than $15 \%$ of the subjects. Twelve subjects $(20.3 \%)$ consumed water-spinach sautéed as the iron intake from vegetable. Dumplings, cilok, and bakwan were snacks which were most widely consumed by the subject.

After conducting the normality test of the data, the data of iron intake for each category were not normally distributed with $p$-value 
Table 2 Hemoglobin Level between Stunting and Non-stunting Group

\begin{tabular}{|c|c|c|c|c|}
\hline \multirow{2}{*}{ Height per age } & \multicolumn{3}{|c|}{ Hemoglobin levels (g/dl) } & \multirow{2}{*}{ p-value* } \\
\hline & $\mathrm{F}$ & Mean(SD) & Median (min - maks) & \\
\hline Stunting & 28 & $12.95(0.90)$ & $13.05(11.3-14.4)$ & 0.025 \\
\hline Non-stunting & 31 & $13.66(1.35)$ & $13.5(11.4-16.3)$ & \\
\hline
\end{tabular}

Table 3 Iron Intake between Stunting and Non-stunting Group

\begin{tabular}{lcccc}
\hline \multirow{2}{*}{ Height per age } & \multicolumn{3}{c}{ Iron intake (mg/day) } & \multirow{2}{*}{ p-value* } \\
\cline { 2 - 4 } & $\mathrm{F}$ & Mean (SD) & Median (min - maks) & \\
\hline Stunting & 28 & $23.9(24.39)$ & $15.35(3-115)$ & 0.457 \\
Non-stunting & 31 & $23(22.66)$ & $17.6(4-116)$ & \\
\hline Note: ${ }^{*}$ Mann-Whitney test analysis & & & &
\end{tabular}

$=0.000$, so the data were analyzed using a Mann-Whitney U test.

Data in table 3 showed that there was no significant difference in iron intake in stunting and non-stunting adolescents in this study.

Data intake was categorized into less intake and adequate intake as recommended by National Recommended Dietary Allowances 2013. This was followed by data analysis of the iron intake to hemoglobin concentration to determine the differences in hemoglobin level between normal and low iron intake groups. Similar to the previous data, these categories were not normally distributed, so a MannWhitney test was performed.

This study discovered that there was no difference of hemoglobin level between normal and low iron intake groups.

\section{Discussions}

The results of this study showed a significant difference in hemoglobin levels between stunting and non-stunting adolescent. This indicated that the iron status in stunting adolescent was lower than non-stunting adolescent. This result was consistent with the study conducted by Yustina et al. ${ }^{7}$ The study stated that female adolescents aged
10-12 years who suffer from anemia have body weight, body height, and BMI that are significantly lower than female adolescents aged 10-12 years who are not anemic. ${ }^{7}$ Other study conducted by Yuniar ${ }^{8}$ discovered that there is no significant difference between hemoglobin level and anthropometric status in stunting and non-stunting adolescent. The lower concentration of hemoglobin in adolescents with stunting will cause impairment in the process of oxygenation to the cells and tissues, so that metabolism in the body will be disturbed, such as the Kreb's cycle stage in the process of formation of energy metabolism which plays an important role in generating 2 succynil co-A. 2 succynil co-A is the basic ingredient in the further formation of hemoglobin. If it is not treated immediately, it will cause hemoglobin levels always low and the process of metabolism for rapid growth that occurs in early adolescent will be impaired. ${ }^{4}$

This study showed that iron intake of female subjects aged 12-14 years was below standard of The National Recommended Dietary Allowance 2013 which is $26 \mathrm{mg}$ /day. Nevertheless, the other age groups and male subjects had an average which fulfilled The National Recommended Dietary Allowances

Table 4 Hemoglobin Level between Normal and Low Iron Intake

\begin{tabular}{lcccc}
\hline \multirow{2}{*}{ Iron Intake } & \multicolumn{3}{c}{ Hemoglobin levels (g/dl) } & \multirow{2}{*}{ p value* } \\
\cline { 2 - 4 } & $\mathrm{F}$ & $\operatorname{Mean}(\mathrm{SD})$ & Median $(\mathrm{min}-$ maks $)$ & \\
\hline Low & 37 & $13.38(1.08)$ & $13.5(11.3-16.2)$ & 0.182 \\
Normal & 22 & $13.23(1.42)$ & $13.0(11.4-16.3)$ & \\
\hline
\end{tabular}

Note: * Mann-Whitney test analysis 


\section{3 standard.}

The analysis of the iron intake towards height status showed the value of $p=0.457$, so it can be concluded that there is no significant difference in the iron intake between stunting and non-stunting adolescents. This is in line with the study conducted by Aubuchon-Endsley et al. ${ }^{9}$ that there is no significant difference in the average of the iron intake between the stunting and non-stunting adolescents. ${ }^{9}$ This contrasts with the results of Lyfia et al. ${ }^{10}$ study, which reported that there is an increase of height in elementary school students who have been given iron therapy. This can occur because the growth process is not only a factor of iron, but the growth involves various factors, such as hormonal factors which play a lot at the time of adolescent, genetic factors, environmental factors, and other nutrient factors which are interrelated each other. ${ }^{6,11}$

This study showed that hemoglobin in stunting adolescent was lower than nonstunting adolescent, although the amount of iron intake in both groups showed no difference. According to a theory, when iron intake is low, the effect will reduce the hemoglobin levels in the blood and low hemoglobin level is an indicator of the decrease of ferritin concentration in the body. However, the intake of iron can be affected by various factors; one of them is the iron absorption factor iron which can be inhibited by the intake of other food. Adequate iron intake will still inhibit the absorption process when inhibiting food intake is consumed simultaneously. ${ }^{4}$ This causes hemoglobin levels still low despite everyday iron intake is fulfilled. In addition, the protein also plays an important role in the hemoglobin synthesis. If iron intake is adequate but insufficient protein intake is less, the binding of heme and globin stage is not going to happen, so hemoglobin concentration will be still low. ${ }^{4}$

This study showed that there was no significant difference in hemoglobin levels in adolescents who had less iron intake and those who had adequate iron without considering both normal height or shorter, with $\mathrm{p}=0.182$. However, study conducted by Arifin et al. ${ }^{12}$ showed that iron intake has a significant relation with the incidence of anemia among primary school students. This difference is probably due to the consumption of food containing iron is different in every place and the iron absorption is strongly influenced by the type of source of heme and non-heme iron as well as the presence or absence of inhibitors in food containing iron, such as phytate which was contained in tea and factors that help increased absorption iron such as vitamin C., ${ }^{4,12}$

Limitation of this study was the method of taking dietary intake. The accuracy of dietary history method was higher than the other method, such as Semi Quantitative Food Frequency questionnaire that was used in this study. Although the accuracy was lower, Semi Quantitative Food Frequency questionnaire was effective for measuring long-term intake and specific food that was appropiate for the objective of study. The food intake such as protein, vitamin $\mathrm{C}$, calcium, and other nutrients that influence metabolism, synthesis of $\mathrm{Fe}$ content and synthesis of erythrocytes were not analyzed in this study. Interviewing parents or guardians was not conducted, so the presupposition of information could not be avoided in the study. The limited time and cost made the numbers of sample that were taken limited, although the minimum total sample had been fulfilled.

This study concluded that the level of hemoglobin in stunting adolescent was lower than non-stunting adolescents. The iron intake in stunting and non-stunting adolescents did not show any significant difference. A suggestion for further research is the study should be conducted by using a dietary history interview so that the intake can be more accurate and detailed. Furthermore, the dietary intake of other nutrients, such as protein, vitamin $\mathrm{C}$, calcium, and the types of food that can enhance and inhibit the absorption of iron can be added in the data collection questionnaire.

\section{References}

1. Black RE, Allen LH, Bhutta ZA, Caulfield LE, De Onis M, Ezzati M, et al. Maternal and child undernutrition: global and regional exposures and health consequences. The lancet. 2008;371(9608):243-60.

2. Badan Penelitian dan Pengembangan Kesehatan. Riset Kesehatan Dasar 2013. Jakarta: Kementrian Kesehatan Republik Indonesia;2013.

3. Souganidis E. The relevance of micronutrients to the prevention of stunting. Sight and Life. 2012;26 (2):10-8.

4. Shils ME, Shike M, Ross AC, Caballero B, Cousins RJ, editor. Modern nutrition in health and disease. 10th ed. Philadelphia: Lipincott William and Wilkins; 2006.

5. Ramakrishnan U, Nguyen P, Martorell R. Effects of micronutrients on growth of children under $5 \mathrm{y}$ of age: meta-analyses of 
single and multiple nutrient interventions. Am J Clin Nutr. 2009;89(1):191-203.

6. Arnelia. Karakteristik remaja dengan riwayat gizi buruk dan pendek pada usia dini. J Gizi Pangan. 2011;6(1):42-50.

7. Yustina Anie Indriastuti Kurniawan, Siti Muslimatun, Endang L. Achadi, Soemilah Sastroamidjojo. Nutritional status of adolescent girls in rural coastal area of Tangerang district. Maj Kedok Indon. 2007;57(5):140-5.

8. Yuniar Rosmalina, Fitrah Ernawati. Hubungan status zat gizi mikro dengan status gizi pada anak remaja SLTP. Penel Gizi Makan. 2010;33(1):14-22.

9. Aubuchon-Endsley NL, Grant SL, Berhanu G, Thomas DG, Schrader SE, Eldridge D, et al. Hemoglobin, growth, and attention of infants in southern Ethiopia. Child Dev. 2011;82(4):1238-51.

10. Lyfia D, Deliana M, Hakimi NR, Lubis B. Growth velocity in elementary school children with iron deficiency anemia after iron therapy. Paediatr Indones. 2009;49(5):249-52.

11. Kusuma KE, Nuryanto N. Faktor risiko kejadian stunting pada anak usia 2-3 tahun (Studi di Kecamatan Semarang Timur). Journal of Nutrition College. 2013;2(4):523-30.

12. Arifin SU, Mayulu N, Rottie J. Hubungan asupan zat gizi dengan kejadian anemia pada anak sekolah dasar di kabupaten Bolaang Mongondow Utara. Jurnal Keperawatan. 2013;1(1):1-8. 